UDC 130.2:796

BILOHUR, VLADA,

Doctor of Philosophy, professor, Head of the Department of theory and methodology of physical education and sport of disciplines, Melitopol State Pedagogical University named after Bogdan Khmelnitsky (Melitopol, Ukraine) E-mail: bilovlada@mail.ru

\title{
PROBLEM OF FORMATION OF THE PERSON IN THE WORLD SPORTS WITH POSITION PHILOSOPHICAL-ANTHROPOLOGICAL
}

The article analyzes the cultural foundations of personality in the sport, which tempers the person both physically and spiritually; justified that in the context of philosophical and anthropological analysis of sport acts as a process of appropriation inherent powers of man; proved that anthropological examination of the world of sports is the completion of the process of objectification, that acts as a kind of self-reflection man is directed to the formation of integrity; clarified the issue of sexual dimorphism underlying sociocultural (gender) differences in male and female sports.

Keywords: personality, philosophy, sports, integrated personality, sports personality, and cultural dimensions of sport, philosophical and anthropological discourse, physical culture, sexual dimorphism.

The context of our study is based on the concept of "personality" as the definition of cultural formation principles of integrity in sport, integrating, firstly, organic, biological, congenital behavioral aspects of personality; Second, cultural norms and forms of activity groups, which include the individual; thirdly, typical roles performed in different cultural situations. Scientists believe that the analysis of cultural foundations of personal development should be the following dimensions: 1) epistemological; 2) axiological; 3) regulation; 4) anthropological. Therefore, the cultural foundations of establishment and development of the whole person in the sport - a socially predetermined level of creative, conscious human activity as the mature, objectified in sporting values, traditions and norms.

Adequate understanding of sports activities is possible only through the study of man in its entirety. Most philosophers have studied integrity, insisting that the subject that realizes itself in sport should be considered from the perspective of integral functioning in the environment. Holistic identity as an athletic relationship is determined by conscious activity and its exclusivity in sports communications system formed a joint sports activities. Of active sports person in the context of the knowledge of the sporting world by means of will, energy, activity, intelligence, thinking, human experiences. Sports personality is a link, through which is the physical hardening of the younger generation. Becoming sports personality as a 
whole due to the fact that the individual in sporting activities with other individuals with this change transforms himself as a person. As V.V.Vizitey notes, "if sport is basically still positive in terms of social and cultural activities, the educational technology should be built with a focus on the development of objectively inherent sports potential" [1, p.120]. Sports person goes to the highest goal - winning in sports activities that require education integrity of the individual in the context of which will be high demand implementation of the rights in the world of sport, which is determined by the essential structures («dynamic essential systems"). The last cause of sports consciousness and behavior of man and transformed into joint sports activities (principle of activity-mediated) caused by the degree of awareness of their relationship and reality.

Methods of cultural principles of formation and development of the whole person in the sport - it means and techniques aimed to study the anthropological displays of personality. In the context of the establishment and development of the integrity of sports personalities stand out, especially approaches to defining the essence of sports personality and as individuals, as the subject of sports activities and the system of interpersonal relations1) as the ideal sport's representation in other groups, which include individuals, 2) the subject of sports activities and the system of interpersonal relations in the process of communication with their own kind; 3 ) as the perfect representation of yourself in other people and comparing themselves with others against physical, technical, tactical condition). Sports orientation subject represented design techniques and psychosomatic self-individual athlete aimed at developing cultural foundations existentially-sporting life - communication, formation of social maturity of personal or public recognition, receiving a unique sports experience even at an early age.

Therefore, "self-regulation - is the" force field "movement of human existence in the sport „, which" mediated directly "and influence the formation of the system as a single organism ... as self-realization of his identity, boundless self, decisive choice himself in any situation "[2, p.81]. "Force field" principles of cultural formation and development of the whole person in the sport reveal the cultural dimensions of personality that are manifested through the development of organic, biochemical, innate behavioral preconditions of personality, through the phenomena of activity, which manifests its self-realization; through various cultural situations in which an individual acts as object and subject of the established process. Holistic nutrition person should have a developed consciousness and self-awareness, including awareness of mental regulation of some important aspects of the activity. This should include the analysis of individual integrity and unity of the material foundations of the spiritual content of the human psyche, since man is a unity of mind and body, and it must respond to the dichotomy its existence not only through the thought process but all their life, their feelings and actions.

Philosophy of Sport, which has just formed, aims at identifying the content of human relations, because it involves understanding sports as personal fulfillment, one of the ways which serves objectified process that turns on its objectification of subjectivity and individuality. As Y.Andros notes, "... philosophical anthropology focuses on invariant (in this case human), stable natural anthropic cultural and 
personal qualities, taken in their socio-historical yield, specificity in respect of a certain age" [3, p.5]. The philosophy of sport, which is now formed as a scientific field, involves a philosophical-anthropological discourse that focuses on identifying sports personality of the person in the context of objective forms and relations in sport. The philosophy of sport in the context of philosophical and anthropological analysis makes it possible to understand the sport as a result of the appropriation of the world of man. These products represent world cultural rights.

Relations in the sport clearly reflected in the dialectic of natural and artificial biosphere and nosphere, and not only reduce philosophy to sports products objectification of the physical world of man. Therefore, in our opinion, should be based on objective and subjective unity in the world of sport, and, consequently, the mutual one another. The process of objectification of physical and spiritual nature of man is manifested in sport, as well as possessing the physical data person sports excel in sports, and it's implementing both physical and spiritual and cultural identity. Philosophical and anthropological analysis of the formation of cultural foundations of becoming whole person in sports comes down to the following provisions: 1) Consciousness whole person is the product anthropic socio cultural genesis; 2) products objectification spiritual and cultural world the whole person is only in the material and subject, in this case, sports, and activities; 3) Most sporting activities is part of objective reality for each of trends in the context of changes [4,311p.].

Indeed, what is the philosophical and anthropological analysis of the research problem comes to the problem of personality, individuality, subjectivity, self-worth individual in need of anthropological analysis, as carrier's objectifications of sports are the subjects of a certain culture media that promote their culture reification in the world of sports. Also, keep in mind the fact that the philosophy of sport reveals objective predetermination of the subjective factor, the interaction of objective and subjective, which contributed to a deeper appeal to the subjective world of the individual in the world of sport and which ends its activities in the sports world and the end of his athletic career, faced with many problems exist and faces many problems (health, financial problems, loneliness, disability).

Within modern anthropological approach to analyze the integrity of the individual in the sports world were opened objectification and selection criteria anthropological examination of issues in the world of sports, relationships and transformations that would help overcome the political and economic reduction to sports highest achievements. It only anthropological analysis contributes to the highest physical and spiritual interests of individual rights as a specific subject of sports activities and create conditions for overcoming alienated forms of objectification world sports personality as a subject transforming activity [5, C134142]. In the context of the anthropological analysis of the anthropological examination of a separate group, this aims to transform the sports activities in individual and needs to be reformed. Economic assessment includes some economic indicators, reflecting the concept of economic efficiency sports activities in the business environment plays a significant role. Political expertise includes the political effectiveness of transformations taking place in the country. Actually people, their needs and interests, and desires advantages exist only in the abstract in the context of 
economic and political performance, so only anthropological examination draws attention to the problems of human based assessment of their compliance reforms and man's place in the modern sports world.

Therefore anthropological examination of the world of sports is a necessary continuation and natural completion of the process of objectification, that acts as a kind of self-reflection, making that person really understands itself true active subject of sports history of the state, being the creator of your own sport, which appear essential powers of man. Consequently, subject area anthropological examination of the world of sports is determined by the following successive stages: 1) analysis of the physical phenomena of human development; 2) the process of objectification of the physical and spiritual world in direct sports activities; 3) implementation of the results achieved in the context of objectification and subjection, that the effect of achieving adequate filling its meaning. Using philosophical and anthropological analysis, we focus first on the phenomenon of human knowledge, which must first comprehend its existence as such, and then it takes root. It sports real life includes real connection between "I" and being in which man realizes his essence. A person who is closely associated with the sports world, are part of this world, and it is a world that is refracted through man and realized in human nature. After being located in each of us, while there is an "us and through us." The objective being is a physical and spiritual world that has value to the person who sells its - essence and gives all its meaning being by identifying mental states. Formation of the cultural foundations of becoming whole person in sports in the context of philosophical and anthropological analysis shows that individualization of a man in the sports world is used to describe organic human being, different aspects of her life.

The concept of "individualization" indicates the man as "cultural atom" is an inseparable element of social life. The concept of individualization points to overcome the individual shape and atomicity elementary, the conversion of philosophy forming the cultural foundations of the formation of the whole person in the world (philosophical-anthropological discourse) sport being in the form of personal fulfillment. Personalization man in the world of sports is determined by the following factors: 1) natural and biological (natural environment); 2) social (labor and its social development, communication, language, culture, family, social differentiation, training, education, religion).

Personalization - content is the most important aspect anthropic socio cultural genesis, based on fundamental-primary basis of physical development of the individual and his physical hardening. The human individualization - a characteristic philosophy of sport, which is historical, attributive present throughout the process and is anthropic socio cultural genesis dialectical unity attributiveness and situational. Intensive development of an individuality in the sports world (diversity of its forms) begins with the formation of secondary reflection (the second level of the individual), that is that people are beginning to realize its individualization, which are beginning to realize in sport (self-respect, self-esteem, self-presentation, self-actualization).

Therefore individualization integrity - an expression of the essence of his personality, which is constantly in a state of reflection and self-reflection (introspection) and is able to develop as a person who seeks his destiny in the world 
of sports, as has all the physical data that needs service "... something higher with regard to man and his material and rational, every day, every day needs; in the ministry that is out of reach, trouble and creative vitality "[6, p.33]. Sports personality - a personality, able to freely determine their goals sports activities (promotion), to adjust their activities in case of discrepancy means goals. But philosophers certify that each personality can uterine varying complexity, differently possess its form, its relative stability system, imagine yourself harmony, but the actual harmony parts and is the basis of personality Consequently contradictory combination of the human qualities of openness and closeness of their minds it however, is subjective and reproduction of objective reality of the external world and consciousness, which serves inner core of spirituality sports world. This is seen relatively isolated from the outside world inside the world system with their values, life plans, deeply personal feelings, self-esteem and abuse. The inner world of sports rights is constantly working, and measure voltage of sports rights is a measure of spiritual and physical wealth personality measure of his personality. As O.P.Punchenko notes, "In objective terms, culture is due to the social, economic, political and spiritual development of society, but in the subjective depending on the extent of social and spiritual development. The unity of subjective and objective expressed in the fact that culture is a measure that reflects the level of development of society and the individual "[7, p.62].

Sport results as products of spiritual and physical inner world of the individual objectified and embodied in the various social and cultural forms, relationships, institutions. Difficult transition from a closed system to an open system personality sportsman making its specific contribution to the general sports culture civilization development - physical and spiritual culture that makes personal creation of human subjects of sports personality of the athlete is characterized by its individuality, that individual level playing generic nature rights, and the products of their sports activities surrounding reality changes and the breakdown unique contribution to sports development as an individual and society. Individuality, characterizing the integrity of the individual, formed in the Renaissance and the Enlightenment, a system of inherited and acquired properties such as originality, exclusivity, uniqueness, which is a direct expression of human nature and its individual sports being - creative, bright, independent healthy, holistic hardened physically and spiritually personality forming invariants, constants sports culture and its universals in the context of categories being the limit [7, 416p]

In our view, the concept of individuality for the establishment of the integrity of sports personalities including content unique physical and spiritual world of man, as not all men are athletes. Individual and derivative individuality - is an attempt to understand the integrity of a particular subject, determining whether a person be themselves distinctive and unique personality; a complete description of the sports personality, revealing it as a single and multilevel structure that is associated with a holistic view of the individual and is manifested as the biological, so the mental and social levels. Not accidentally, the term "identity" refers to the unity of the diverse world of sports, especially in the context of globalization, varies, there are many new and modern sports that did not exist before. 
In order to explain how nature appears "individuality" in the world of sports, sports person should present not only as open, but as a closed system. Individuality as a complete system includes the following attributes inherent in a group of athletes: 1) attributes that characterize the individual as a representative species of society and 2) special signs specific to participants in specific sports situations; 3) the specific individual items of its cultural and social environment. Sporting integrity identity as formed in the context of its impact on the cultural factors of modern society that has cultural existence in which single and universal, natural and social interaction, telling each other and merging into a complete cultural formation of the individual as a whole. Because sports personality due to the influence of cultural factors differently manifested in the sports world. Therefore it out and appropriate forms of individual realization: subject, biological, social, cultural. The most common signs of identity, especially in sports, is the integrity, originality, uniqueness, activity that in the less inherent in all its forms. Revealing identity as cultural integrity is not in the list of special features, and in determining its main system factor, which determines the integrity of the individual.

Essential-universal factors integrity of the individual in the sports world are the originality, the ability to be themselves within the natural, social and cultural whole, endurance, forming hardening sports personality. Only on this basis, given the uniqueness and originality, reveal its internal structure and mechanism of formation. The integrity of the individual, the image formed by the sports personality, organically included in the general communications, reveals its place in sports existential situations which element it is. This concept of sporting integrity of the individual, which is based on the cultural foundations of modern society, makes it possible to link it with the processes and trends in cultural development, as disconnected from the public, the integrity of the individual does not exist.

But junk is also the other extreme - the construction of the other extreme - the construction individual properties only one sports person, because individuality is lost or universal, general or individually. Giving a holistic view of a person in the integrity of individual and common properties, the notion of individuality characterize it as being specific, given the autonomy of its existence. Each representative of the human race - a single original world that is being included in the social structure retains its relative independence. For every personality acquires independence thanks to the role it plays in society. Because personality is not to be understood as absolute independence of the individual from the outside world, but it does not dissolve in the community, each individual having their skills and capabilities, should form the individual style of his life. This sport is a lifestyle filled with their values. This leads to the need for individual autonomy and human activity through its self in the world of sport and filling it with their sporting values.

Thus, the formation of cultural foundations of becoming whole person in sports in the context of philosophical and anthropological analysis considering integrated identity through the world of culture as a way of being human in unity identify unique and common, natural and social, cultural and anthropological sections of sporting life, which manifested individual properties and personality characteristics. Essential trends of spreading society, standardization, depreciation, alienation and 
leveling man at the beginning of the XXI century it raise the question of human right in a civilized existence. This requires increasing the role and contribution in all areas of full social and practical life, including sports. In the theory of physical culture developed long problem of sexual dimorphism, which is the basis of social and cultural (or, as they are called, gender) differences in male and female sports. "Dimorphism" - the presence within the same species (in our case - Homo sapiens) two more or less disparate forms.

According to experts, the main drawback of most current research in the theory of physical culture is that the assessment of scientific results is made without regard to sexual dimorphism. Meanwhile, only this approach allows us to determine the objective causes of the current problems of women's sports, eliminates beyond gender study the problems of physical culture in general. If many types of biological sex differences do not play a significant role and is all about professionalism man, whether he man or woman, in different sports. Physicality plays it as important as the social and cultural settings; athletic achievement is always associated with physical features and capabilities of men and women. Biological capacity of individual preference explains verbal (verbal, linguistic) abilities in spatial abilities of girls and boys, although in the last 20 years these parameters under the influence of sociocultural factors have become more similar.

To differences in perception can be attributed to the following facts: women are more observant, attentive to detail, even (so they sought as witnesses in criminal cases, compiling a photo while men focus on details, details often do not pay). Sexual dimorphism is noticeable in sports activities. The biggest difference between athletes of both sexes is in the size of their bodies. Men taller and heavier women, the size of man's heart more than the female. Differences in power depend on that overall women less than men (remember how important, for example, the size of a hand in some sports). But this aggregate data. Among both sexes are carriers of individual features, also should be considered. Female, whatever the level of training as unarmed fighter can hardly resist the man skilled in the sport. Theoretically, of course, possible, but in practice it requires a tremendous amount of physical and spiritual efforts over a long period of time. Women - huge melee fighters - in the past and on the verge of myth. With an increase feminist ambitions of absolute equality when competition is proposed to excluding sexual dimorphism, i.e., "according stature and weight," threat to the health of women also increased, so that just be equality still cannot. It is clear that the greater height and weight respectively greater and lung capacity. As stated by Dariusz Blahnio Institute of Physiology of the Warsaw Academy of Physical Education, a leader of men in most sports disciplines is not in danger, as they are more favorable proportion of muscle mass relative to total body weight, "Even a strengthened training will not ensure ambitious ladies testosterone - the male sex hormone responsible for muscle development.» From the perspective of sexual dimorphism clear contrast the success of women in swimming: their fat layer serves as a kind of insulation (known records of American Lynne Cox, for the first time in the world swam from Alaska to Chukotka across the Bering Strait, and record Penny Dean, who managed to independently overcome English Channel). Thus, in the sports of biological opposition male / female seen quite clearly 
because of the specific object of study, sports achievements are always associated with physical opportunities for men and women enshrined bit system standards and indicators. Physicality is the most important manifestation of human potential, as in sports always take into account the natural foundations of socio-cultural gender.

\section{СПИСОК ВИКОРИСТАНИХ ДЖЕРЕЛ}

1. Визитей H. Н. Соцฺилогия спорта: Курс лекичй. - К.: Олимпийская литература, 2005.-247c.

2. Білогур В. С. Екзистениійні засади спорту як самовизначення особистості / В. $С$. Білогур // Філософія як культурна політика сучасності. Тези доповідей всеукрайнської наукової конференції.- Острог : Видавництво Національного університету «Острозька академія», 2013. - 122 c.

3. Андрос 6 . Специфіка та визначальні виміри сучасного філософськоантропологічного знання / $C$. Андрос // Визначальні виміри сучасного філософськоантропологічного знання // Зб. наук. Пращь : Філософсько- антропологічні студії' 2013.$351 \mathrm{c}$.

4. Білогур В. Є. Світоглядні орієнтації студентів: тенденції змін у трансформаційному суспільстві : [Монографія] / В. С. Білогур.- Дніпропетровськ :Пороги, 2011. $-311 \mathrm{c}$.

5. Воронкова В. Г. Формирование нового мировоззрения, нового человека, нового общества будущего : [Монография] / В. Г. Воронкова / Кого и как воспитывать в подрастающих поколениях // Под ред. О.А.Базалука .- К.: Издательский дом «Скиф».- 2012. T.2. - C. 134-152.

6. Екзистенщійні виміри філософсько-антропологічного пізнання: творча спадщина В. Шинкарука : матеріали Міжнар. наук.- практ. конф., 14 квіт. 2011 р. / Київ. нац.. ун-т ім. Тараса Шевченка, Т-во «Знання» України, Ін-т філос. ім. Г. С. Сковороди НАН України, Унт сучас. знань. - К.: Т-во «Знання», Украӥни, 2011. - 339 с.

7. Пунченко О. П. Цивилизаџионное измерение истории человечества / О.П.Пунченко. - Oдесса : Астропринт, 2013. - 448 .

8. Кирилюк О. С. Світоглядні категорії граничних підстав в універсальних вимірах культури : Монографія. / О. С.Кирилюк. - Одеса : Центр гуманітарної Освіти НАН України. Одеський філіал / Автограф.- 2008.- 415 c.

\section{REFERENCES}

1. Visits N. Sociology of Sport: Lectures. - K.: Olympyyskaya literature, 2005. - 247 p.

2. Bilohur V. Existential foundations of sport as self-identity / V.Bilohur // Philosophy as Cultural Politics of today. Abstracts of the All-Ukrainian scientific conference. - Jail: Publisher of National University "Ostrog Academy", 2013. - 122p.

3. Y.Andros Specificity and constitutive dimensions of modern philosophical and anthropological knowledge / Andros // Defining dimensions of contemporary philosophical and anthropological knowledge // Collection. Science. Works, philosophical anthropological studio' 2013. - $351 \mathrm{p}$.

4. Bilohur V. Ideological orientation of students, trends in social transformation: [Monograph] / V.Bilohur. - Dnepropetrovsk: thresholds, 2011. - 311p.

5. Voronkova V. Formation new outlook, a new man, a new society of the future: [Monograph] / V.Voronkova / Who and how to educate a younger generation // Ed. O. A. Bazaluka. - K. : Publishing House "Skif». - 2012. - T.2. - P. 134-152.

6. Existential dimensions of philosophical and anthropological knowledge, artistic heritage V. Shynkaruka materials Intern. sciences. - Pract. Conf., Apr 14. 2011 / Kyiv. Nat. University of them. Taras Shevchenko "Knowledge" of Ukraine, Institute of Philosophy. National Academy of Sciences of Ukraine, University of modern knowledge. Production of "Knowledge", Ukraine, 2011. - 339 p. 
7. Punchenko O. Civilizational dimension of human history / O.P.Punchenko. - Odessa: Astroprint, 2013, 448 p.

8. Kyrylyuk O. Ideological reasons to limit the category of universal dimensions of culture: Monograph. / O. Kyrylyuk. - Odessa Center of Humanitarian Education Sciences of Ukraine. Odessa branch /2008. - Avtohraf. - 415 p.

БІЛОГУР В. Є. - доктор філософських наук, професор, завідувач кафедри теорії методики фізичного виховання та спортивних дисциплін Мелітопольського державного педагогічного університету імені Богдана Хмельницького (Мелітополь, Україна) E-mail: bilovlada@mail.ru

\section{ПРОБЛЕМА СТАНОВЛЕННЯ ОСОБИСТОСТІ В СВІТІ СПОРТУ 3 ПОЗИЦӤ ФІЛОСОФСЬКОЇ АНТРОПОЛОГЇ̈}

В статті дається аналіз культурних засад становлення особистості у спорті, який загартовує людину $i$ фізично, $i$ духовно; обтрунтовується, щзо в контексті філософськоантропологічного аналізу спорт виступає як процес привласнення іманентних сил людини; доведено, щзо антропологічна експертиза світу спорту є завершенням процесу об'єктивації, тобто виступає як своєрідна саморефлексія людини, направлена на становлення иілісності; з'ясовано питання статевого диморфізму, що лежить в основі соціокультурних (гендерних) відмінностей в чоловічому і жіночому спорті.

Ключові слова: особистість, філософія спорту, иілісна особистість, спортивна особистість, культурні виміри спорту, філософсько-антропологічний дискурс, фізична культура, статевий диморфізм.

Билогур В. Е. - доктор философских наук, профессор, заведующая кафедрой теории и методики физического воспитания и спортивных дисциплин Мелитопольского государственного педагогического университета имени Богдана Хмельницкого, (Мелитополь, Украина) E-mail: bilovlada@mail.ru

\section{ПРОБЛЕМА СТАНОВЛЕНИЯ ЛИЧНОСТИ В МИРЕ СПОРТА С ПОЗИЦИИ ФИЛОСОФСКОЙ АНТРОПОЛОГИИ}

В статье дается анализ культурных основ становления личности в спорте, который закаляет человека и физически, и духовно; обосновывается, что в контексте философско антропологического анализа спорт выступает как процесс присвоения имманентных сил человека; доказано, что антропологическая экспертиза мира спорта является завершением процесса объективации, то есть выступает как своеобразная саморефлексия человека, направленная на становление целостности; выяснен вопрос половой диморфизм, что лежит в основе социокультурных (гендерных) различий в мужском и женском спорте.

Ключевые слова: личность, философия спорта, целостная личность, спортивная личность, культурные измерения спорта, философско-антропологический дискурс, физическая культура, половой диморфизм

Стаття надійила до редколегії 07.11.16 p.

Рекомендовано до друку 12.11.16 p. 